(C) 2022, The Authors. Published by Elsevier Inc. and Fass Inc. on behalf of the American Dairy Science Association ${ }^{\circledR}$. This is an open access article under the CC BY license (http://creativecommons.org/licenses/by/4.0/).

\title{
Development of a spray-dried conjugated whey protein hydrolysate powder with entrapped probiotics
}

\author{
Shayanti Minj ${ }^{1,2}$ and Sanjeev Anand ${ }^{1,2 *}$ (1) \\ ${ }^{1}$ Midwest Dairy Foods Research Center, St. Paul, MN 55108-6074 \\ ${ }^{2}$ Dairy and Food Science Department, South Dakota State University, Brookings 57007
}

\begin{abstract}
Bifidobacterium animalis ssp. lactis ATCC27536 and Lactobacillus acidophilus ATCC4356 were encapsulated in a conjugated whey protein hydrolysate (WPH10) through spray drying. Probiotic cultures were added at the ratio of 1:1 into the conjugated WPH10 solution at a spiking level of about $10 \log _{10} \mathrm{cfu} / \mathrm{mL}$. The mixture was spray dried in a Niro drier with inlet and outlet temperatures of $200^{\circ} \mathrm{C}$ and $90^{\circ} \mathrm{C}$, respectively. The final dried product was determined for cell viability and further stored for $16 \mathrm{wk}$ at $25^{\circ}, 4^{\circ}$, and $-18^{\circ} \mathrm{C}$ to monitor viability and functionality. Micro images showed the presence of link bridges in non-conjugated WPH10, whereas, in the case of conjugated WPH10, round particles with pores were observed. The mean probiotic counts before and after spray drying were $10.59 \log _{10}$ $\mathrm{cfu} / \mathrm{mL}$ and $8.98 \log _{10} \mathrm{cfu} / \mathrm{g}$, respectively, indicating good retention of viability after spray drying. The solubility and wetting time of the WPH10-maltodextrin (MD) encapsulated probiotic powder were $91.03 \%$ and $47 \mathrm{~min}$, whereas for WPH10, the solubility and wetting time were $82.03 \%$ and 53 min, respectively. At the end of storage period, the counts were $7.18 \log _{10} \mathrm{cfu} / \mathrm{g}$ at $4^{\circ} \mathrm{C}$ and $7.87 \log _{10} \mathrm{cfu} / \mathrm{g}$ at $-18^{\circ} \mathrm{C}$, whereas at $25^{\circ} \mathrm{C}$ the counts were significantly reduced, to $3.97 \log _{10} \mathrm{cfu} / \mathrm{g}$. The solubility of WPH-MD powder was $82.36 \%, 83.1 \%$, and $81.19 \%$ at $-18^{\circ} \mathrm{C}, 4^{\circ} \mathrm{C}$, and $25^{\circ} \mathrm{C}$, respectively, and wetting times were $61 \mathrm{~min}, 60 \mathrm{~min}$, and $63 \mathrm{~min}$ at $-18^{\circ} \mathrm{C}, 4^{\circ} \mathrm{C}$, and $25^{\circ} \mathrm{C}$, respectively. By contrast, for WPH10 powder, the solubility significantly reduced to $69.41 \%, 69.97 \%$, and $68.99 \%$ at $-18^{\circ} \mathrm{C}, 4^{\circ} \mathrm{C}$, and $25^{\circ} \mathrm{C}$, and wetting times increased to $71 \mathrm{~min}, 70 \mathrm{~min}$, and $72 \mathrm{~min}$ at $-18^{\circ} \mathrm{C}, 4^{\circ} \mathrm{C}$, and $25^{\circ} \mathrm{C}$, respectively. The conjugated WPH10 is thus demonstrated as a promising carrier for probiotics and can be further used as an ingredient for developing functional foods, to har-
\end{abstract}

Received July 7, 2021.

Accepted October 29, 2021

*Corresponding author: Sanjeev.Anand@sdstate.edu ness their enhanced functionality and health benefits derived from both WPH and probiotics.

Key words: probiotics, conjugated, whey protein hydrolysate, encapsulated, functionality

\section{INTRODUCTION}

According to the Food and Agriculture Organization of the United Nations, probiotics are defined as "live microorganisms which when administered in adequate amounts confer a health benefit on the host" (Culligan et al., 2009). The 2 most common genera of probiotic microorganisms are Bifidobacterium spp. and Lactobacillus spp. (de Araújo Etchepare et al., 2020). To acquire beneficial effects, it is recommended that, at the time of consumption, the foods containing probiotics should contain $10^{6}$ to $10^{7}$ live cells per milliliter or gram of the product (Tripathi and Giri, 2014). However, several technological factors, including temperature, $\mathrm{pH}$, moisture, nutrient depletion, and osmotic and oxidative stress, pose considerable challenges in incorporation of these bacteria in different food matrices (Wilkinson, 2018). In addition, resistance to gastrointestinal conditions has always been a major objection (de Araújo Etchepare et al., 2016).

Microencapsulation technology has been widely known to increase the stability of probiotics with controlled release characteristics (Zanjani et al., 2014). Spray drying is one of most used techniques in the microencapsulation process, due to its short time, low cost, and good stability and quality of end products (Mis Solval, 2011; Felix et al., 2017). Compared with other conventional microencapsulation techniques, the spray drying process can be easily scaled up to produce microcapsules in a continuous processing operation (Ré, 1998; McHugh 2018). A variety of encapsulants, including alginate, milk protein concentrates and isolates, and lipids, have been studied (Ragavan and Das, 2018; Yasmin et al., 2019). However, large-scale production of gel beads, their large size diameters, dispersion, and requirement of transfer from organic solvents present serious difficulties in food applications 
(Picot and Lacroix, 2003). In the case of milk whey proteins, although they have been a versatile nutritionally beneficial system, enriched with bioactive properties, major challenges related to their low thermal stability are faced. At high processing temperatures, whey proteins tend to destabilize, leading to denaturation, gelation, foaming, and decreased solubility (Adjonu et al., 2013). At high ionic strength, they are inclined to aggregation, which causes sedimentation during storage (Mulcahy et al., 2016).

The thermal stability of whey proteins has been addressed by conjugating them with reducing carbohydrates (Yang et al., 2012). Proteins conjugated with a reducing carbohydrate through a Maillard reaction process have shown to exhibit improved physiological and functional properties, including heat stability, solubility, emulsification capacity, water binding and antioxidant activity (Zhang and Zhong, 2010). During the early stages of heating, conjugation occurs, where a covalent bridge is formed between protein and carbohydrate molecules. This interlinkage of the carbohydrate side chains with protein limits the aggregation between proteins and peptides, which in turn increases protein hydration and steric repulsion between proteins (Sosa et al., 2016). In view of the potential benefits of probiotics and conjugation, the intent of the present work was to study the effect of microencapsulation of probiotics in a conjugated whey protein on the viability and functionality of the end product. In our previous studies, a whey protein hydrolysate (WPH10) conjugate was developed by conjugating the protein with maltodextrin. The conjugate exhibited higher bioactive attributes (Minj and Anand, 2019) and, hence, was used to encapsulate probiotic cultures Bifidobacterium and Lactobacillus through a spray drying process. The product was stored at different temperature conditions to evaluate the viability of probiotic organisms and functional properties.

\section{MATERIALS AND METHODS}

\section{Ingredients}

The WPH10, with a 10\% degree of hydrolysis and $89.98 \%$ protein, was procured from a commercial dairy plant. Maltodextrin with a dextrose equivalent of 10 was purchased from Sigma-Aldrich.

\section{Preparation of WPH10-Maltodextrin Conjugate}

The WPH10-maltodextrin (MD) conjugate solution was prepared according to the protocol described by Mulcahy et al. (2016). The WPH10 (5\% wt/vol, protein) and maltodextrin (dextrose equivalent $=10$;
$5 \% \mathrm{wt} / \mathrm{vol}$ ) were dispersed in distilled water at room temperature and mixed under magnetic stirring for at least $2 \mathrm{~h}$ to ensure complete dissolution. The $\mathrm{pH}$ of the mixture was then adjusted to 8.2 with $0.5 \mathrm{~N} \mathrm{KOH}$ and allowed to hydrate for $18 \mathrm{~h}$ at $4^{\circ} \mathrm{C}$. After hydration, the $\mathrm{pH}$ was readjusted to 8.2 with $0.5 \mathrm{~N} \mathrm{KOH}$. Further, the solution was transferred to a conical flask and heated at $90^{\circ} \mathrm{C}$ for $24 \mathrm{~h}$ in a shaking water bath. At the end of the heating period, the conjugated solution was cooled to room temperature for microencapsulation.

\section{Probiotic Cultures and Inoculum Preparation}

Pure freeze-dried probiotic cultures (Bifidobacterium animalis ssp. lactis ATCC27536 and Lactobacillus acidophilus ATCC4356) were obtained from ATCC. Fresh cultures were obtained after 2 respective transfers in de Man, Rogosa, and Sharpe broth supplemented with $0.05 \%$ (wt/vol) L-cysteine $37^{\circ} \mathrm{C}$ for $72 \mathrm{~h}$, under anaerobic conditions. Propagation of the cultures were continued, and the cells were harvested in their late log phase by centrifugation at $7,000 \times g$ for $10 \mathrm{~min}$ at $4^{\circ} \mathrm{C}$. The cell pellets were washed twice in PBS $(0.9 \%)$ and suspended to achieve cell suspensions of $10 \log \mathrm{cfu} / \mathrm{mL}$. These cell suspensions were mixed in a ratio of 1:1 into the conjugated solution before microencapsulation.

\section{Probiotic Cell Microencapsulation}

The earlier inoculated whey protein hydrolysatemaltodextrin conjugate solution was spray dried in a pilot spray dryer (Atomizer Versatile Utility Spray Dryer, Niro). The solution was fed into the dryer by a peristaltic pump at a flow rate of $110 \mathrm{~mL} / \mathrm{min}$ and a compressed air pressure of 55 psi. The inlet and outlet air temperatures were maintained at $200^{\circ} \mathrm{C}$ and $90 \pm$ $5^{\circ} \mathrm{C}$, respectively. The obtained spray-dried probiotic powder was collected and analyzed for viability of probiotic. The WPH10 without maltodextrin was used as a control to represent the non-conjugated sample. Mixing of maltodextrin with WPH10 without heating (or conjugation) and maltodextrin alone led to coagulation and a sticky product during spray drying conditions and, hence, could not be used as controls for the encapsulation process.

\section{Viability of Probiotics and Encapsulation Yield}

Viability of the probiotic organisms was evaluated by standard pour plate technique. One gram of each powder sample was drawn out, and serial dilutions were made using PBS. The diluted samples were plated on de Man, Rogosa, and Sharpe agar supplemented with $0.05 \%$ (wt/vol) L-cysteine. The plates were incubated 
at $37^{\circ} \mathrm{C}$ for $72 \mathrm{~h}$ under anaerobic conditions. Total count was taken in log cfu per gram. Viable counts were taken before and after spray drying to determine the survival rate (i.e., encapsulation yield, EY), calculated as follows:

$$
\mathrm{EY}=\frac{\log \mathrm{N}}{\log \mathrm{N}_{0}} \times 100
$$

where $\mathrm{N}_{0}$ is the viable count (in log cfu/g) of dry powder before spray drying, and $\mathrm{N}$ represents the viable count (in $\log \mathrm{cfu} / \mathrm{g}$ ) of dry powder after spray drying.

\section{Morphological Analysis by Scanning Electron Microscopy}

The surface morphology of the WPH-MD conjugate entrapped probiotic powder was evaluated by scanning electron microscopy according to Yang et al. (2012) and Rosenberg et al. (1985). Spray-dried powder samples were coated with $10 \mathrm{~nm}$ of gold under vacuum by finecoat ion sputter. Scanning electron microscopy was carried out at an accelerating voltage of $5 \mathrm{kV}$, and the images were captured with magnifications of $5,000 \times$ and $10,000 \times$.

\section{Moisture Determination}

The moisture content of the spray-dried probiotic powder was determined according to IDF (1993) standard 26A. First, $1 \mathrm{~g}$ of dry powder sample (A) was weighed into a porcelain dish. The dish was placed in a hot-air oven at $103^{\circ} \mathrm{C}$ for 4 to $5 \mathrm{~h}$. At the end, the sample was drawn out and cooled, and the weight was measured (B). The moisture content was calculated as follows:

$$
\left(\frac{\mathrm{A}-\mathrm{B}}{\mathrm{A}}\right) \times 100
$$

where $\mathrm{A}=$ initial weight of the sample, and $\mathrm{B}=$ final weight of the sample.

\section{Storage Studies}

The collected spray-dried WPH10 conjugate encapsulated probiotic powder was packaged in airtight containers and stored at temperatures of $-18,4$, and $25^{\circ} \mathrm{C}$. During storage, the samples were pulled out after $2,4,8,12$, and 16 wk to monitor cell viability, moisture content, and functionality. The probiotic cell viability during storage was analyzed according to the standard plate technique method described previously.

\section{Functional Properties}

Solubility. The protein solubility of the WPH10-MD conjugate encapsulated probiotic powder was analyzed according to the method of Westergaard (2004). In a beaker, $100 \mathrm{~mL}$ of distilled water was taken at room temperature, and $5 \mathrm{~g}$ of sample $(p)$ was added. The suspension was stirred for $30 \mathrm{~min}$ using a magnetic plate stirrer. The $\mathrm{pH}$ of the solution was $6.77 \pm 0.05$. Next, $40 \mathrm{~mL}$ of the solution was drawn out in a tube, weighed, and centrifuged at $7,000 \times g$ for $10 \mathrm{~min}$ at room temperature. The supernatant was transferred carefully in a pre-dried $\left(1 \mathrm{~h}\right.$ at $103 \pm 2^{\circ} \mathrm{C}$, cooled in desiccators) and pre-weighed aluminum bowl. It was dried for 4 to $5 \mathrm{~h}$ in an oven at $103 \pm 2^{\circ} \mathrm{C}$, cooled, and weighed $(y)$. Solubility (\%) was calculated as follows:

$$
\% \text { Solubility }=100-\left(\frac{y}{p} \times 100\right)
$$

where $y=$ final weight after drying, and $p=$ initial weight of the sample.

Wettability. The method used to calculate wettability was an extension of the International Dairy Federation method (IDF, 1979). The method essentially measures the time for a given mass of powder to sink beneath the water surface, referred to as the wetting time. First, $250 \mathrm{~mL}$ of distilled water was weighed in a $600-\mathrm{mL}$ dry beaker and heated to $50^{\circ} \mathrm{C}$ (ensuring that the inner side of the beaker, just above the water level, remains dry). Next, $10 \mathrm{~g}$ of sample was taken and slowly added with the help of a dry cone and aluminum foil (held with a stand) over the water. The time was recorded immediately after all the powder was added, until all the powder particles had sunk below the surface of the water.

\section{Statistical Analysis}

Experiments were performed in triplicate, and oneway ANOVA was applied to differentiate between mean values. All figures with error bars were made using Sigmaplot software version 13 (SPSS Inc.) for Windows 10 (Microsoft Corp.).

\section{RESULTS AND DISCUSSION}

\section{Viability of Probiotics and Encapsulation Yield}

The achievement of high viability of probiotic organisms throughout the drying and storage period is challenging and is classified as one of the major problems in producing a commercial probiotic food (Mounsey and O'Riordan, 2008). For efficacy, the recommended 
Table 1. Viability of the probiotic microorganisms in the conjugated whey protein hydrolysate (WPH10-MD) after spray drying, and its encapsulation efficiency $(\%)^{1}$

\begin{tabular}{lccc}
\hline Sample & $\begin{array}{c}\text { Before drying } \\
(\log \text { cfu/mL) }\end{array}$ & $\begin{array}{c}\text { After drying } \\
(\log \text { cfu/g) }\end{array}$ & $\begin{array}{c}\text { Encapsulation } \\
\text { yield }(\%)\end{array}$ \\
\hline WPH10 encapsulated probiotic powder (control) & $10.62 \pm 0.01^{\mathrm{a}}$ & $4.03 \pm 0.02^{\mathrm{c}}$ & $37.94 \pm 0.17^{\mathrm{d}}$ \\
WPH10-MD encapsulated probiotic powder & $10.58 \pm 0.08^{\mathrm{a}}$ & $8.98 \pm 0.02^{\mathrm{b}}$ & $84.87 \pm 0.02^{\mathrm{e}}$ \\
\hline
\end{tabular}

${ }^{\mathrm{a}-\mathrm{e}}$ Values followed by different superscripts are significantly different $(P<0.05)$.

${ }^{1}$ Mean $\pm \mathrm{SD}(\mathrm{n}=3)$.

viable probiotic counts in a probiotic food are $10^{6}$ to $10^{7} \mathrm{cfu} / \mathrm{g}$ (Tripathi and Giri, 2014). Table 1 and Figure 1 show the viability of probiotic organisms in the conjugated WPH10 matrix through spray drying and 16 -wk storage of the microcapsules at $-18,4$, and $25^{\circ} \mathrm{C}$. After spray drying, the probiotic cell counts obtained in the conjugated WPH10 matrix were $8.98 \pm 0.02 \log _{10}$ $\mathrm{cfu} / \mathrm{g}$, with an encapsulation yield of $84.87 \pm 0.02 \%$. However, when probiotic cells were encapsulated in non-conjugated WPH10 (control), under similar spray drying conditions, viable counts of $4.03 \pm 0.02 \log _{10}$ $\mathrm{cfu} / \mathrm{g}$ were achieved, with an encapsulation yield of $37.94 \pm 0.17 \%$. These results imply good retention of the viability of probiotics in the conjugate carrier, with a higher survival rate compared with non-conjugated WPH10. Higher survival in the WPH10 conjugate is likely due to improved thermal resistance of the WPH10 and modification of the particle to a matrix type following conjugation with maltodextrin. The use of mixtures of whey proteins and carbohydrates or fats are currently being studied, to enhance the stability of whey proteins as carriers. It has also been reported that use of proteins and polysaccharide mixtures can help link proteins to protect lactic acid bacteria (Nale et al., 2018) and can also be used as a dietary fiber under gastrointestinal conditions (Salavati Schmitz and Allenspach, 2017). Picot and Lacroix (2004) reported that entrapment of Bifidobacterium spp. through spray drying in a heat-denatured whey protein isolate (WPI) carrier containing milk fat can be suitable in terms of cell viability compared with WPI alone. Guérin et al. (2003) investigated the viability of probiotics entrapped in gel beads coated with WPI conjugated with pectin, under gastrointestinal conditions. They observed that the resistance of the cells to acidic and bile conditions was enhanced with a reduction of less than $2 \log$ in the case of coated gel beads. Comparatively, the survival of the cells in free form and in the uncoated gel beads was lower, with 4 to $7 \log _{10}$ reduction. In a study conducted by Oliveira et al. (2007), Bifidobacterium spp. and Lactobacillus spp. were encapsulated in a casein and pectin matrix by coacervation, followed by spray drying; those authors found that the wall material was efficient in protecting the microorganisms during dry- ing and in gastrointestinal conditions. In another study, Lacticaseibacillus rhamnosus GG was encapsulated at $10^{9} \mathrm{cfu} / \mathrm{mL}$ in a formulation prepared using WPI and maltodextrin through spray drying, and the results showed only $1 \log$ reduction of the bacteria, with improved survival during storage conditions (Ying et al., 2012).

\section{Morphology of the WPH Conjugate Encapsulated Probiotic Microcapsules}

Following spray drying, the morphology of WPH10 before and after conjugation and after entrapment of the probiotic microorganisms in the conjugated WPH10 were analyzed through scanning electron microscopy. The images from scanning electron microscopy are presented in Figure 2. In the images of non-conjugated WPH10, the powder particles were non-porous smooth spheres. However, some link bridges between the particles and disruption of the structures could be observed after drying. This explains the high hygroscopicity of the whey protein and low thermal stability of the particles. However, in the case of conjugated WPH10, a matrix-type structure could be observed, where the particles presented a round, porous surface. This confirms a modification of the whey protein particle structure after conjugation. In this study, greater viability of probiotic organisms was observed in the matrix-type particles (conjugated whey protein) compared with the non-porous spherical particles (non-conjugated whey protein), making the conjugated whey protein suitable for encapsulation. Further, the addition of maltodextrin decreased the hygroscopicity of the particles, which restricted the formation of link bridges. In Sidlagatta et al. (2020), addition of maltodextrin to sweet orange juice was shown to inhibit sugar crystallization and increase the glass transition temperature. Similar observations were reported by Yang et al. (2012), whose morphological analysis of a spray-dried whey protein hydrolysate through scanning electron microscopy before conjugation showed a smooth surface with link bridges between the particles, whereas after conjugation with $\beta$-maltodextrin, the particles presented a matrix-type surface with fewer link bridges and many 
pores. In Rocha et al. (2009), after conjugation of a casein protein hydrolysate with maltodextrin, similar matrix-type microspheres were produced.

After entrapment of probiotic cells in the conjugated WPH10, varying sizes of microcapsules were produced, in the range of 10 to $20 \mu \mathrm{m}$ in diameter. The images are displayed in Figure 3. Scanning electron micro images of the microencapsulated probiotic powder showed no free or non-encapsulated cells on the outside or on the surface of the microcapsules, which indicates successful entrapment of the probiotics with a high encapsulation efficiency. To confirm this, the powder particles were dispersed in distilled water ( $1 \mathrm{~g}$ in $9 \mathrm{~mL}$ of water) and observed under light microscope (Figure 2). The images clearly show the probiotic cells around the broken con-
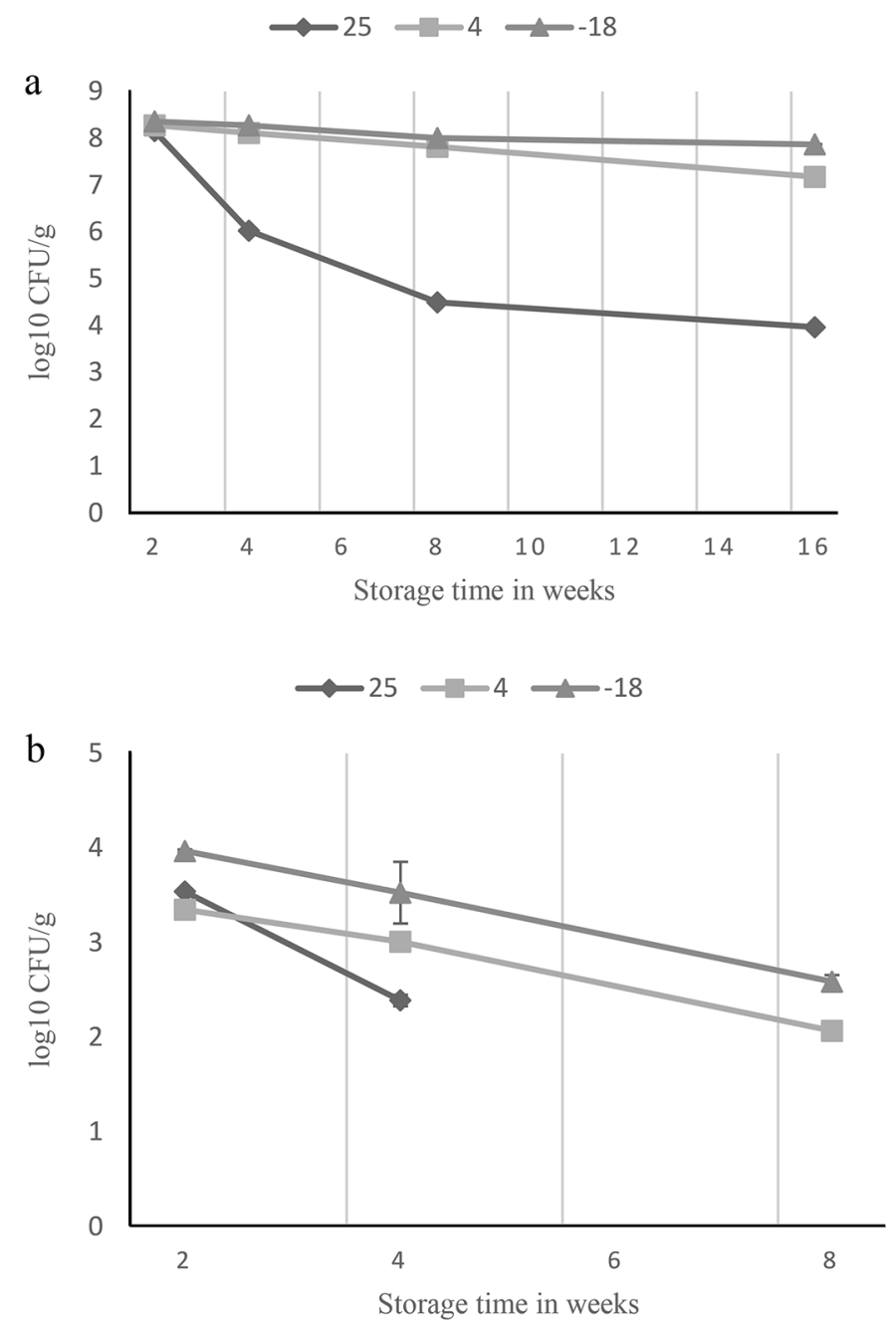

Figure 1. Viability of probiotic organisms in (a) conjugated (WPH10-MD) encapsulated probiotic powder, compared with (b) nonconjugated whey protein hydrolysate (WPH10) entrapped probiotic powder, during storage at $-18,4$, and $25^{\circ} \mathrm{C}$ for 16 wk. Error bars represent SEM from 3 independent experiments. jugate particles and some inside the pores. This verifies that the matrix structure of the conjugated WPH10 is maintained even after the microencapsulation and shows that the cells remained entrapped within the carrier material. These observations are comparable to Bifidobacterium infantis entrapped microcapsules produced using a caseinate-fructooligosaccharide-oil dried glucose syrup emulsion (Crittenden et al., 2006). However, the microcapsules produced in our work provide advantages because of their smaller size compared with beads produced using alginates, gelatin, or xanthan gums (typically $>100 \mu \mathrm{m}$ in diameter), which affects the mouthfeel and texture when added into food matrices (Sun and Griffiths, 2000; Krasaekoopt et al., 2004; Crittenden et al., 2006).

\section{Moisture Determination}

Moisture content is one of the important factors in determining the shelf stability of food products. It also affects the physical and chemical characteristics of a food, which influence the freshness and storage stability of the food for a long period of time (Isengard, 2001). Both the non-conjugated and conjugated entrapped probiotic powders showed moisture contents of $0.91 \pm$ $0.08 \%$ and $0.64 \pm 0.14 \%$ (i.e., below $5 \%$ ), which is recommended in spray-dried powders for preventing cell loss during storage of dried cultures (Peighambardoust et al., 2011). The moisture content in the microcapsules was greatly influenced by the outlet temperature and the cubic effect of the outlet temperature, suggesting that temperature plays an important role in the drying process (Felix et al., 2017). Hence, with a higher outlet temperature of $90 \pm 5^{\circ} \mathrm{C}$ and an inlet temperature of $200^{\circ} \mathrm{C}$, a powder with low moisture content was produced.

\section{Viability of Probiotics During Storage}

Viability of probiotic microorganisms during storage conditions is an important criterion for foods containing probiotics. Therefore, the WPH10 conjugate-entrapped probiotic microcapsules were stored at $25^{\circ} \mathrm{C}, 4^{\circ} \mathrm{C}$, and $-18^{\circ} \mathrm{C}$ for $16 \mathrm{wk}$, to monitor cell viability and compared with non-conjugated WPH10. The results are shown in Figure 1. Throughout storage at 4 and $-18^{\circ} \mathrm{C}$, the probiotic counts were maintained, and at the end of the storage period, a reduction of approximately $1 \log _{10}$ $\mathrm{cfu} / \mathrm{g}$ was observed, with final counts of $7.18 \pm 0.008$ and $7.87 \pm 0.008 \log _{10} \mathrm{cfu} / \mathrm{g}$, respectively. At $25^{\circ} \mathrm{C}$, the counts significantly $(P<0.05)$ dropped to $3.97 \pm 0.008$ $\log _{10} \mathrm{cfu} / \mathrm{g}$. In the case of non-conjugated WPH10 (Figure 3 ), the probiotic counts sharply declined to 2.07 \pm 0.008 and $2.59 \pm 0.069 \log _{10} \mathrm{cfu} / \mathrm{g}$ at 4 and $-18^{\circ} \mathrm{C}$, 
respectively, whereas at $25^{\circ} \mathrm{C}$ storage, the counts declined to $2.39 \pm 0.061 \log _{10} \mathrm{cfu} / \mathrm{g}$ at the end of $4 \mathrm{wk}$, and no counts were observed after 8 wk of storage. Overall, the survival of the organisms was better at $4^{\circ} \mathrm{C}$ and at $-18^{\circ} \mathrm{C}$ at the end of 16 wk than at ambient temperature $\left(25^{\circ} \mathrm{C}\right)$. From these data, it was observed that the stability of the conjugated WPH10 was higher compared with non-conjugated WPH10 under storage conditions, and survival of the cells was higher at 4 and $-18^{\circ} \mathrm{C}$ compared with $25^{\circ} \mathrm{C}$. The final concentration of a1

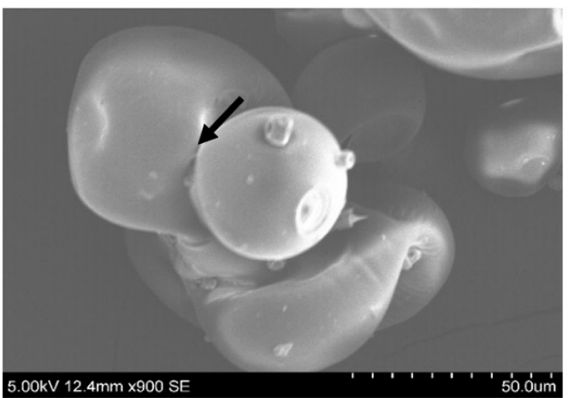

b1

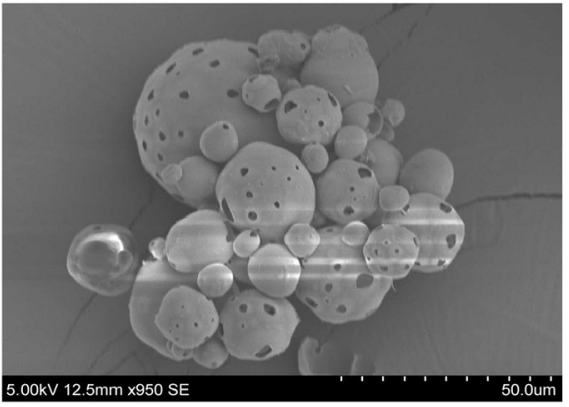

c1

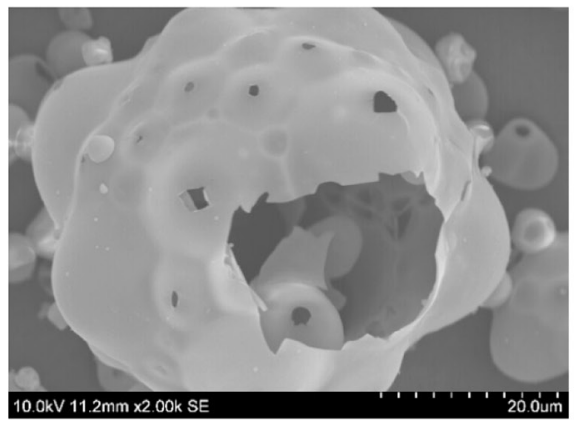

a2

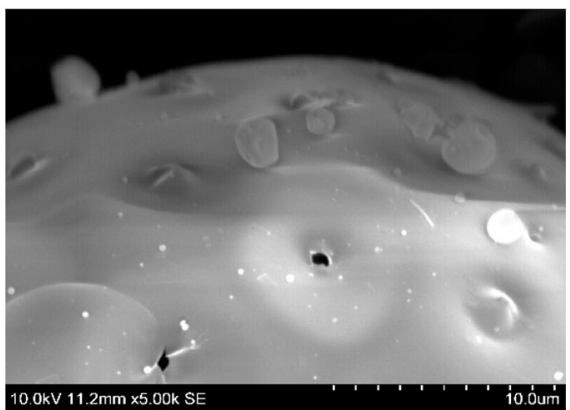

b2

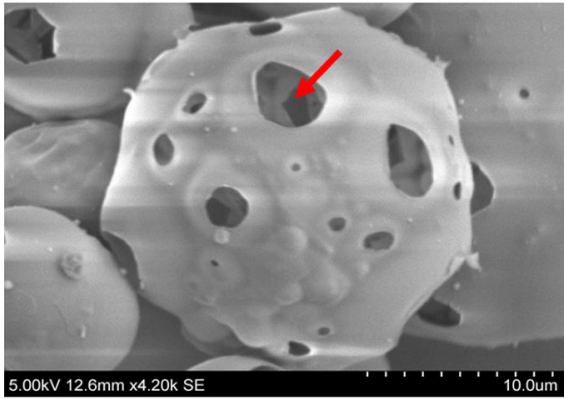

c2

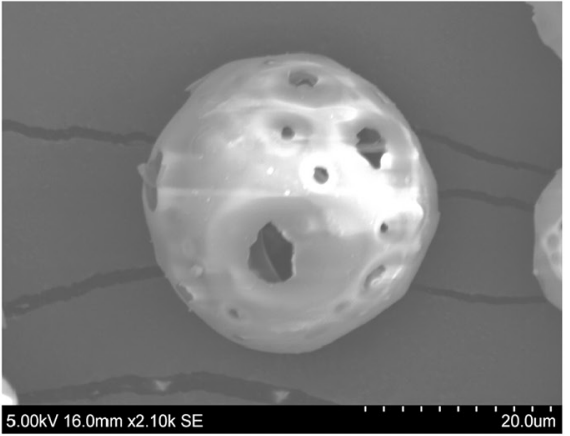

c3

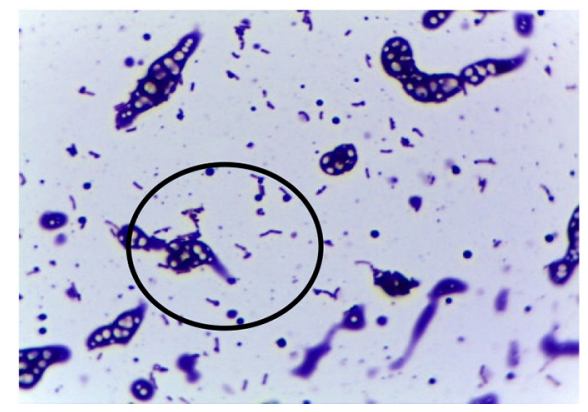

Figure 2. Scanning electron micro images of powder particles, with magnifications from 900 to 5,000. Panels a1 and a2: non-conjugated whey protein hydrolysate (WPH10); b1 and b2: maltodextrin-conjugated whey protein hydrolysate (WPH10-MD); c1: non-conjugated WPH10 entrapped probiotic powder; c2: conjugated (WPH10-MD) entrapped probiotic powder particles; c3: light microscope image of conjugated (WPH10-MD) entrapped probiotic powder $(178-\mu \mathrm{m}$ field of view at $1,000 \times$ magnification). Black arrow indicates the link bridges between WPH10 powder particles. Red arrow indicates the pores on the conjugated WPH10. Black circle indicates probiotic cells surrounding the broken conjugate powder particles. 
$7 \log _{10} \mathrm{cfu} / \mathrm{g}$ of viable cells is within the recommended levels for probiotics in foods (i.e., $10^{6}-10^{7} \mathrm{cfu} / \mathrm{g}$; Anekella and Orsat, 2013).

In one study, Fung et al. (2011) encapsulated $L$. acidophilus in dietary fiber through electrospinning and obtained good survival when stored at $4^{\circ} \mathrm{C}$ for $21 \mathrm{~d}$. In addition, similarly, the thermal resistance of encapsulated probiotics indicates possible protection of cells when incorporated in heat-processed foods. Yasmin et al. (2019) encapsulated Bifidobacterium longum BL-05 and studied its survival at $4^{\circ} \mathrm{C}$ for $28 \mathrm{~d}$. Storage at refrigeration temperatures exhibited a log reduction of 1.72 and 1.99 for all encapsulated treatments. This can be correlated with the present work, in which multilayer microencapsulation using protein and carbohydrate
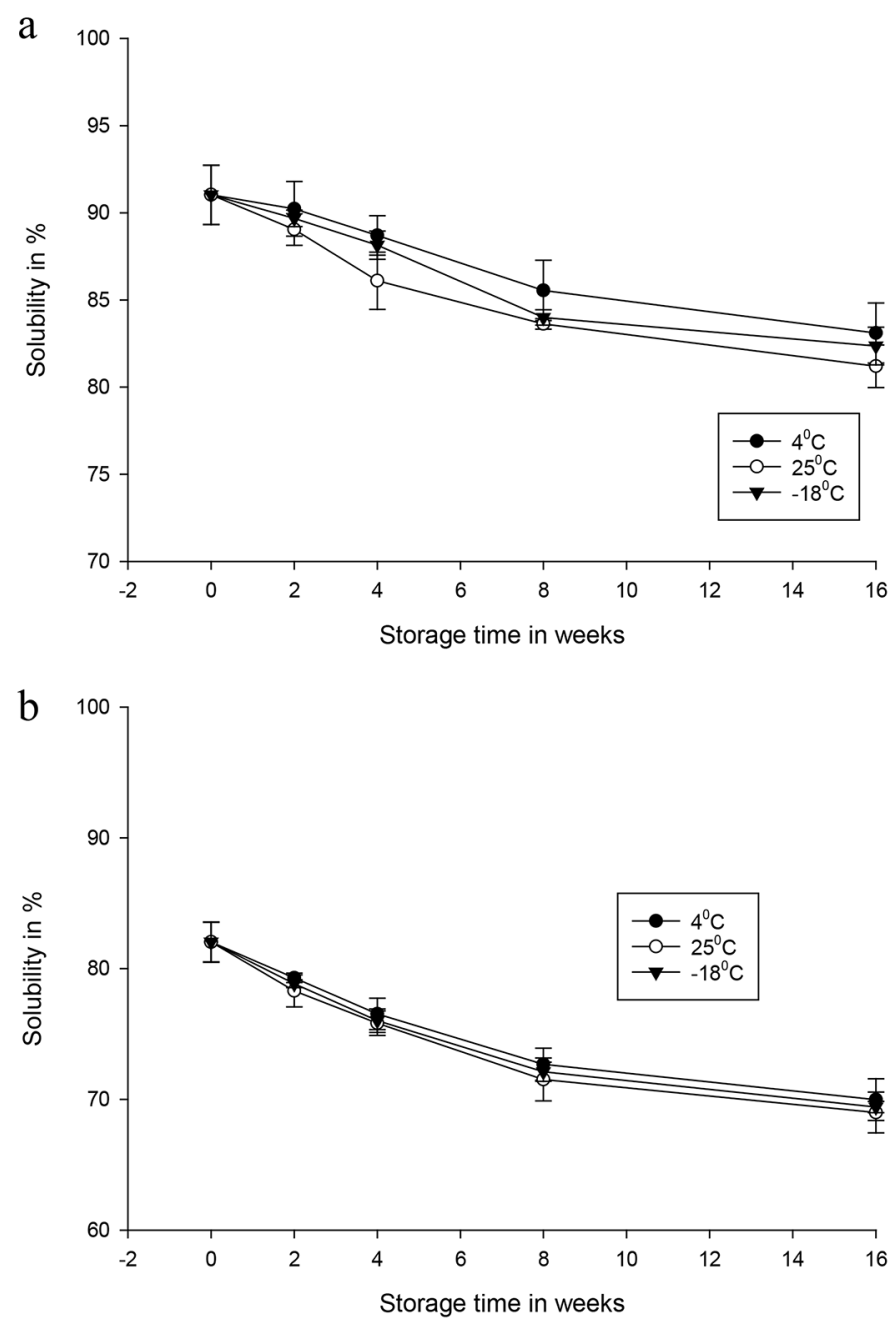

Figure 3. Solubility (\%) of (a) conjugated (WPH10-MD) encapsulated probiotic powder, compared with (b) non-conjugated whey protein hydrolysate (WPH10) entrapped probiotic powder, during storage at $-18,4$, and $25^{\circ} \mathrm{C}$ for $16 \mathrm{wk}$. Error bars represent SEM from 3 independent experiments. mixtures significantly improved the survival of probiotics at $4^{\circ} \mathrm{C}$ during long-term storage.

The results obtained can also be related to a study by $\mathrm{Xu}$ et al. (2016), where a Lactobacillus spp. was encapsulated in a pea protein isolate-alginate matrix and stored at $-15^{\circ} \mathrm{C}$. After $84 \mathrm{~d}$ of storage, the encapsulated bacteria showed the highest survival rate compared with all other samples. It was reported by Conrad et al. (2000) that at freezing temperatures cell death can occur due to formation of ice crystals that can cause structural damage to the cell membranes and result in changes in the physiological state of the cells. However, in our studies, minimal log reduction at $-18^{\circ} \mathrm{C}$ indicates the ability of the conjugated WPH10, as a carrier, to protect cells at freezing temperatures. This makes it suitable to be added to frozen food or to food that that requires freezing.

In storage at $25^{\circ} \mathrm{C}$, the stability of the cells in conjugated WPH10 was maintained, and counts were within the recommended levels up to 4 wk of storage, providing better protection compared with non-conjugated WPH10, which presented a sharp decline within $15 \mathrm{~d}$ of storage. This tells us that, at the analyzed temperature $\left(25^{\circ} \mathrm{C}\right)$, it is difficult to maintain viable counts, and the loss of viability at ambient temperatures may be attributed to changes in the moisture content of the powder, which can lead to cell membrane disruption and deactivation (Ilango et al., 2016). The increase in moisture content with storage time could be associated with moisture absorption from the storage environment. Crystallization of lactose sugar could be another reason, as some amount of water is released during the phase transition from the amorphous state to the crystalline state (Pałacha and Sitkiewicz, 2008). Moreover, the viability of bacteria during storage also depends on the sensitivity of the bacteria to oxygen and the ability of encapsulating material as a protector. Following spray drying, lipid oxidation during storage alters the composition of the lipid cell membrane. Other factors that influence the survival of organisms during storage are the composition of the encapsulated powder, oxygen content, and glass transition temperature. Hence, the viability of organisms during ambient storage conditions could be enhanced by using effective desiccants or deoxidants, suitable packaging material, and vacuum packaging.

\section{Solubility During Storage}

The ability of a powder to completely dissolve in water is termed solubility (Gaiani et al., 2011). The protein solubility of the WPH10-MD encapsulated probiotic powder was analyzed according to the method of Westergaard (2004), with slight modifications, and was 
compared with the control non-conjugated WPH10. The change in solubility from the initial day until 16 wk of storage is displayed in Figure 3. Following spray drying, the solubility of the WPH10-MD encapsulated probiotic powder at the initial day of storage was 91.03 $\pm 0.98 \%$, whereas the solubility of WPH10 was 82.03 $\pm 0.88 \%$. During hydrolysis, the release of specific peptides and exhibition of hydrophobic residues could promote peptide or protein-peptide aggregation, which could be related to the lower solubility of WPH10 powder (Creusot and Gruppen, 2007). In addition, peptides released during hydrolysis possess low molecular masses and reduced secondary structure, which can restrict the changes induced by heat (Chobert et al., 1988). In the case of conjugated WPH10 encapsulated probiotic powder, conjugation offers an advantage. During the process of conjugation, the bulky dextran molecules become attached to the protein molecules, which in turn increases the steric hindrance between the molecules. This thereby increases hydration of the protein (Mulcahy et al., 2016).

Further, both the powder samples were stored at 3 different temperatures $\left(-18,4\right.$, and $\left.25^{\circ} \mathrm{C}\right)$. The samples were withdrawn after $2,4,6,8$, and $16 \mathrm{wk}$, and solubility were analyzed. After 2 wk of storage the solubility of WPH-MD powder was $89.68 \pm 0.27 \%$ for $-18^{\circ} \mathrm{C}$, $90.23 \pm 0.99 \%$ for $4^{\circ} \mathrm{C}$, and $89.05 \pm 0.52 \%$ for $25^{\circ} \mathrm{C}$; whereas for WPH10 powder, the solubility was 78.85 $\pm 0.17 \%$ for $-18^{\circ} \mathrm{C}, 79.3 \pm 0.2 \%$ for $4^{\circ} \mathrm{C}$, and 78.29 $\pm 0.7 \%$ for $25^{\circ} \mathrm{C}$. A slow but continuous decrease in solubility was observed in both the samples. For $8 \mathrm{wk}$ of storage, WPH-MD powder showed relatively good solubility at all the storage temperatures $(>85 \%)$. At the end of wk 10, the solubility of WPH-MD powder declined to $82.36 \pm 0.62 \%$ for $-18^{\circ} \mathrm{C}, 83.1 \pm 0.99 \%$ for $4^{\circ} \mathrm{C}$, and $81.19 \pm 0.7 \%$ for $25^{\circ} \mathrm{C}$; and for WPH10 powder the solubility declined to $69.41 \pm 0.24 \%$ for $-18^{\circ} \mathrm{C}, 69.97 \pm 0.92 \%$ for $4^{\circ} \mathrm{C}$, and $68.99 \pm 0.89 \%$ for $25^{\circ} \mathrm{C}$. The decrease in solubility of the powder samples with storage time is possibly due to the formation of a complex matrix of cross-linked proteins at the surface of the powder, which eventually restricts water transport and subsequently impedes hydration of the powder particles (Anema et al., 2006). However, studies have also shown that solubility will not decrease until a significant level of cross-linking of the protein molecules at the powder surface has occurred, and this may explain why the solubility did not immediately decrease on storage. With storage time and temperature, the degree of cross-linking between proteins increases (Sharma et al., 2012). Hence, the solubility of the powder samples gradually decreased with time, and the samples at room temperature exhibited lower solubility compared with the samples stored at 4 and $-18^{\circ} \mathrm{C}$. Also, Singh et al. (1992) addressed that increase in the moisture level of the milk powder samples during prolonged storage contributes to several changes in the milk protein structure, which leads to decrease in solubility.

\section{Wettability During Storage}

Wettability of food powders is a result of a molecular interaction between solid and liquid phase, and is generally explained as the ability of the powder particles to overcome the surface tension caused by the water. The surface composition of powders plays an important role in the wetting process (Fang et al., 2008).

The wettability of the WPH10-MD encapsulated probiotic powder was analyzed according to IDF, 1979, with slight modifications, and was compared with the reference sample, WPH10. The change in the wetting time from the initial day to $16 \mathrm{wk}$ of storage is displayed in Figure 4. Following spray drying, the wetting time of the WPH10-MD encapsulated probiotic powder at the initial day of storage was $47 \pm 2 \mathrm{~min}$, whereas the wetting time of WPH10 was $53 \pm 2 \mathrm{~min}$. Both the powder samples showed higher wetting times compared with a commercial whole milk powder and skim milk powder ( $>1 \mathrm{~min}$ ), which can be explained by their high protein content as compared with whole milk powder. In both the cases, the powder particles became wet very quickly and turned instantly into lumps surrounded by the gelatinous layer, thereby reducing the wetting of the powder. One possible reason could be the high presence of protein on the surface of the powders. Similar observations have been reported by Silva and O'Mahony (2017) in milk protein concentrate. The WPH10-MD encapsulated probiotic powder showed less wetting time compared with the WPH10 powder, which can be related to the effects of conjugation, as linking of carbohydrate side chains with protein decreases the exposure of protein molecules on the particle surface (Mulcahy et al., 2016). Another possible explanation could be decrease in the hygroscopicity of the particles after addition of maltodextrin. Sharma et al. (2012) explained that, if the particle surface is more hygroscopic, it dissolves too quickly, which thickens the liquid and restricts further penetration of liquid into the powder mass.

Further, both the powder samples were stored at 3 different temperatures $\left(-18,4\right.$, and $\left.25^{\circ} \mathrm{C}\right)$. The samples were withdrawn after $2,4,6,8$, and $16 \mathrm{wk}$, and wetting time were recorded. After 2 wk of storage, the wetting time of WPH-MD powder was $49 \pm 1 \mathrm{~min}$ for $-18^{\circ} \mathrm{C}$, $48 \pm 1 \mathrm{~min}$ for $4^{\circ} \mathrm{C}$, and $50 \pm 1 \mathrm{~min}$ for $25^{\circ} \mathrm{C}$; whereas for WPH10 powder, the wetting time was $56 \pm 1 \mathrm{~min}$ 

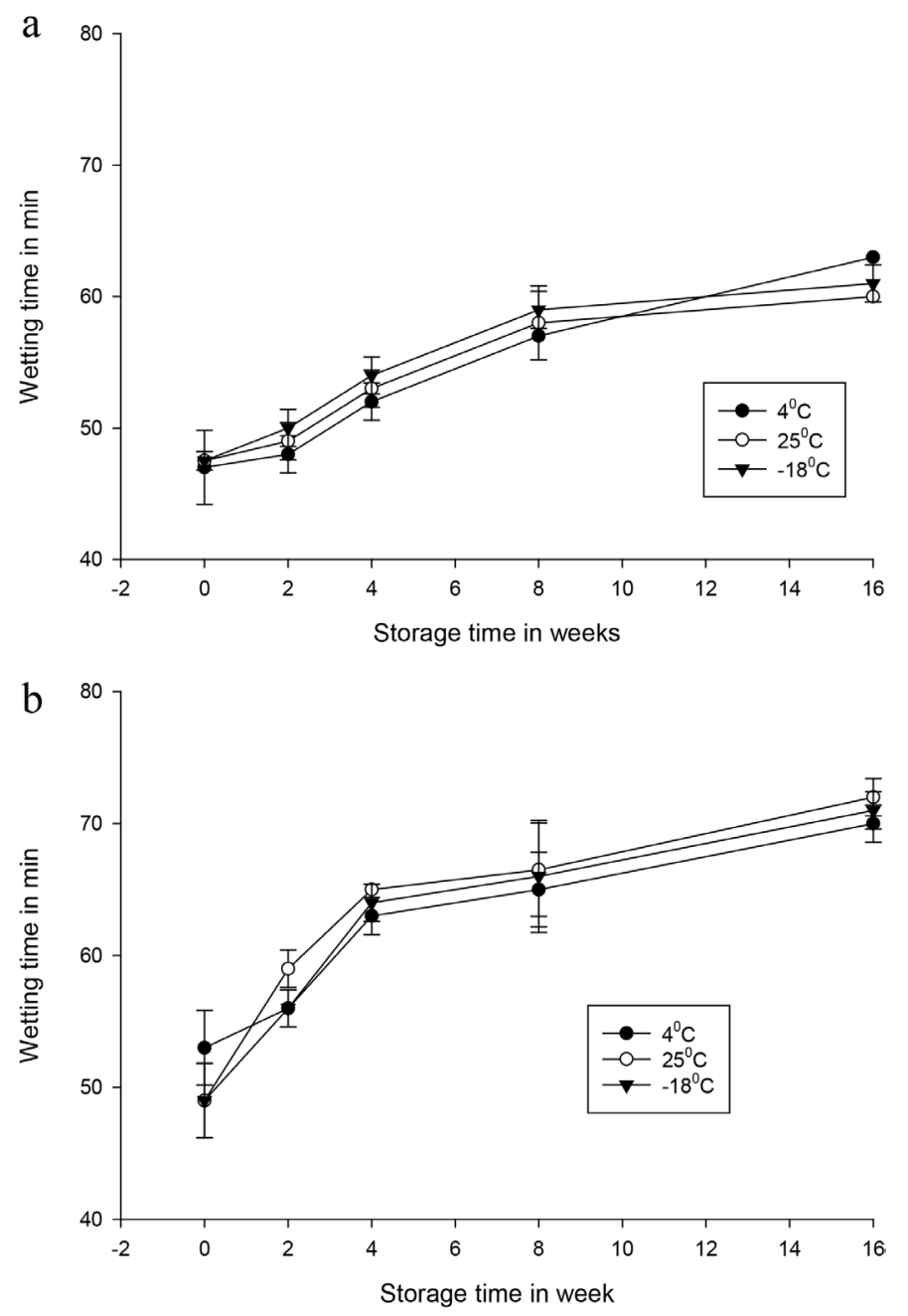

Figure 4. Wetting time (min) of (a) conjugated (WPH10-MD) encapsulated probiotic powder, compared with (b) non-conjugated whey protein hydrolysate (WPH10) entrapped probiotic powder, during storage at $-18,4$, and $25^{\circ} \mathrm{C}$ for 16 wk. Error bars represent SEM from 3 independent experiments.

for $-18^{\circ} \mathrm{C}, 56 \pm 1 \mathrm{~min}$ for $4^{\circ} \mathrm{C}$, and $59 \pm 1 \mathrm{~min}$ for $25^{\circ} \mathrm{C}$. A continuous increase in the wetting time was observed in both the samples, and by the end of wk 16 the wetting time of WPH-MD powder increased to $61 \pm 1 \mathrm{~min}$ for $-18^{\circ} \mathrm{C}, 60 \mathrm{~min}$ for $4^{\circ} \mathrm{C}$, and $63 \mathrm{~min}$ for $25^{\circ} \mathrm{C}$; and for WPH10 powder, the wetting time increased to $71 \pm$ $1 \mathrm{~min}$ for $-18^{\circ} \mathrm{C}, 70 \pm 1 \mathrm{~min}$ for $4^{\circ} \mathrm{C}$, and $72 \pm 1 \mathrm{~min}$ for $25^{\circ} \mathrm{C}$. The increase in the wetting time with storage time can be attributed to the formation of a complex matrix of cross-linked proteins at the surface of the powder, which eventually restricts water transport and subsequently impedes hydration of the powder particles (Anema, 2009). Similarly, Kim et al. (2002) observed a decrease in the rate of wetting with an increase in the swelling of the whey protein concentrate particles.

\section{CONCLUSIONS}

The morphology of the conjugated WPH10 presented a matrix-type microsphere and, hence, was used for encapsulation of probiotic microorganisms. After microencapsulation through spray drying, the conjugated WPH10 demonstrated as a carrier for probiotic microorganisms with viable counts of $8.98 \log _{10} \mathrm{cfu} / \mathrm{g}$ with an encapsulation yield of $84.87 \%$. Hence, the survival rate was significantly higher in the conjugated WPH10 matrix compared with non-conjugated WPH10. Additionally, conjugation of whey protein hydrolysate positively affected the viability of the probiotic cells under different storage temperatures $\left(4^{\circ} \mathrm{C}, 25^{\circ} \mathrm{C}\right.$, and $\left.-18^{\circ} \mathrm{C}\right)$. The microspheres were able to maintain and preserve the viability of the cells throughout the storage period at freezing $\left(-18^{\circ} \mathrm{C}\right)$ and refrigeration temperatures $\left(4^{\circ} \mathrm{C}\right)$. Conjugation with maltodextrin was effective in enhancing the functionality of the final spray-dried product. With the improved solubility and wettability of conjugated whey protein hydrolysate (WPH10-MD) compared with non-conjugated WPH10, WPH10-MD possesses great potential to be incorporated as a food ingredient. Overall, such probiotic powder formulation, with improved functionality and having value-added benefits from both WPH10 and probiotics beyond utilizing their individual benefits, can offer several food applications.

\section{ACKNOWLEDGMENTS}

This work is supported by NIFA Capacity Funded Hatch Project (accession no. SD00H630-18) from the USDA National Institute of Food and Agriculture (Washington, DC). The authors also thank the Midwest Dairy Association (St. Paul, MN) for funding this project and Davis Dairy Plant (Dairy Science Department, South Dakota State University, Brookings) for allowing us to conduct a part of the research work. The authors have not stated any conflicts of interest.

\section{REFERENCES}

Adjonu, R., G. Doran, P. Torley, and S. Agboola. 2013. Screening of whey protein isolate hydrolysates for their dual functionality: Influence of heat pre-treatment and enzyme specificity. Food Chem. 136:1435-1443. https://doi.org/10.1016/j.foodchem.2012.09.053.

Anekella, K., and V. Orsat. 2013. Optimization of microencapsulation of probiotics in raspberry juice by spray drying. Lebensm. Wiss. Technol. 50:17-24. https://doi.org/10.1016/j.lwt.2012.08.003.

Anema, S. G. 2009. Role of colloidal calcium phosphate in the acid gelation properties of heated skim milk. Food Chem. 114:161-167. https://doi.org/10.1016/j.foodchem.2008.09.031.

Anema, S. G., D. Pinder, R. Hunter, and Y. Hemar. 2006. Effects of storage temperature on the solubility of milk protein concentrate (MPC85). Food Hydrocoll. 20:386-393. https://doi.org/10.1016/j .foodhyd.2005.03.015. 
Chobert, J. M., C. Bertrand-Harb, and M. G. Nicolas. 1988. Solubility and emulsifying properties of caseins and whey proteins modified enzymically by trypsin. J. Agric. Food Chem. 36:883-892. https:/ /doi.org/10.1021/jf00083a002.

Conrad, P. B., D. P. Miller, P. R. Cielenski, and J. J. de Pablo. 2000. Stabilization and preservation of Lactobacillus acidophilus in saccharide matrices. Cryobiology 41:17-24. https://doi.org/10.1006/ cryo. 2000.2260 .

Creusot, N., and H. Gruppen. 2007. Hydrolysis of whey protein isolate with Bacillus licheniformis protease: Fractionation and identification of aggregating peptides. J. Agric. Food Chem. 55:9241-9250. https://doi.org/10.1021/jf071584s.

Crittenden, R., R. Weerakkody, L. Sanguansri, and M. Augustin. 2006. Synbiotic microcapsules that enhance microbial viability during nonrefrigerated storage and gastrointestinal transit. Appl. Environ. Microbiol. 72:2280-2282. https://doi.org/10.1128/AEM.72.3 $.2280-2282.2006$.

Culligan, E. P., C. Hill, and R. D. Sleator. 2009. Probiotics and gastrointestinal disease: Successes, problems and future prospects. Gut Pathog. 1:19. https://doi.org/10.1186/1757-4749-1-19.

de Araújo Etchepare, M., G. L. Nunes, B. R. Nicoloso, J. S. Barin, E. M. Moraes Flores, R. de Oliveira Mello, and C. R. de Menezes. 2020. Improvement of the viability of encapsulated probiotics using whey proteins. Lebensm. Wiss. Technol. 117:108601. https:// doi.org/10.1016/j.lwt.2019.108601.

de Araújo Etchepare, M., G. C. Raddatz, E. M. de Moraes Flores, L. Q. Zepka, E. Jacob-Lopes, J. S. Barin, C. R. Ferreira Grosso, and C. R. de Menezes. 2016. Effect of resistant starch and chitosan on survival of Lactobacillus acidophilus microencapsulated with sodium alginate. Lebensm. Wiss. Technol. 65:511-517. https://doi .org/10.1016/j.lwt.2015.08.039.

Fang, Y., G. Sun, Q. Cong, G. H. Chen, and L. Q. Ren. 2008. Effects of methanol on wettability of the non-smooth surface on butterfly wing. J. Bionics Eng. 5:127-133. https://doi.org/10.1016/S1672 -6529(08)60016-5.

Felix, P. H. C., V. S. Birchal, D. A. Botrel, G. R. Marques, and S. V. Borges. 2017. Physicochemical and thermal stability of microcapsules of cinnamon essential oil by spray drying. J. Food Process. Preserv. 41:e12919. https://doi.org/10.1111/jfpp.12919.

Fung, W. Y., K. H. Yuen, and M. T. Liong. 2011. Agrowaste-based nanofibers as a probiotic encapsulant: Fabrication and characterization. J. Agric. Food Chem. 59:8140-8147. https://doi.org/10 $.1021 / \mathrm{jf2009342.}$

Gaiani, C., M. Mullet, E. Arab-Tehrany, M. Jacquot, C. Perroud, A. Renard, and J. Scher. 2011. Milk proteins differentiation and competitive adsorption during spray-drying. Food Hydrocoll. 25:983990. https://doi.org/10.1016/j.foodhyd.2010.09.013.

Guérin, D., J. C. Vuillemard, and M. Subirade. 2003. Protection of Bifidobacteria encapsulated in polysaccharide-protein gel beads against gastric juice and bile. J. Food Prot. 66:2076-2084. https:/ /doi.org/10.4315/0362-028X-66.11.2076.

IDF. 1979. International standard 87. International Dairy Federation.

IDF. 1993. International standard 26A. International Dairy Federation.

Ilango, S., R. Pandey, and U. Antony. 2016. Functional characterization and microencapsulation of probiotic bacteria from koozh. J. Food Sci. Technol. 53:977-989. https://doi.org/10.1007/s13197 -015-2169-5.

Isengard, H. D. 2001. Water content, one of the most important properties of food. Food Control 12:395-400. https://doi.org/10.1016/ S0956-7135(01)00043-3.

Kim, E. H. J., X. D. Chen, and D. Pearce. 2002. Surface characterization of four industrial spray-dried dairy powders in relation to chemical composition, structure and wetting property. Colloids Surf. B Biointerfaces 26:197-212. https://doi.org/10.1016/S0927 -7765(01)00334-4.

Krasaekoopt, W., B. Bhandari, and H. Deeth. 2004. The influence of coating materials on some properties of alginate beads and survivability of microencapsulated probiotic bacteria. Int. Dairy J. 14:737-743. https://doi.org/10.1016/j.idairyj.2004.01.004.
McHugh, T. H. 2018. The significance of spray-drying. Food Technol. $72: 142-146$

Minj, S., and S. Anand. 2019. A conjugated whey protein hydrolysate demonstrates enhanced bioactive attributes. J. Dairy Sci. 102(Suppl. 1):46 (Abstr.).

Mis Solval, K. E. 2011. Spray drying technology for the production and processing of microencapsulated omega-3 fish oil with egg powder. MS thesis. Department of Food Science, Louisiana State University and Agricultural and Mechanical College.

Mounsey, J. S., and E. D. O'Riordan. 2008. Influence of pre-gelatinized maize starch on the rheology, microstructure and processing of imitation cheese. J. Food Eng. 84:57-64. https://doi.org/10.1016/ j.jfoodeng.2007.04.017.

Mulcahy, E. M., D. M. Mulvihill, and J. A. O'Mahony. 2016. Physicochemical properties of whey protein conjugated with starch hydrolysis products of different dextrose equivalent values. Int. Dairy J. 53:20-28. https://doi.org/10.1016/j.idairyj.2015.09.009.

Nale, Z., I. Tontul, A. Aşçi Arslan, H. Sahin Nadeem, and A. Kucukcetin. 2018. Microbial viability, physicochemical and sensory properties of kefir microcapsules prepared using maltodextrin/arabic gum mixes. Int. J. Dairy Technol. 71:61-72. https://doi.org/10 $.1111 / 1471-0307.12402$.

Oliveira, A. C., T. S. Moretti, C. Boschini, J. C. C. Baliero, O. D. Freitas, and C. S. Fávaro-Trindade. 2007. Stability of microencapsulated B. lactis (BI 01) and L. acidophilus (LAC 4) by complex coacervation followed by spray drying. J. Microencapsul. 24:673681. https://doi.org/10.1080/02652040701532908.

Pałacha, Z., and I. Sitkiewicz. 2008. Glass transition temperature- $\mathrm{Pa}-$ rameter for food stability. Przemysł Spozywczy. 62:32-37.

Peighambardoust, S. H., A. Golshan Tafti, and J. Hesari. 2011. Application of spray drying for preservation of lactic acid starter cultures: A review. Trends Food Sci. Technol. 22:215-224. https:/ /doi.org/10.1016/j.tifs.2011.01.009.

Picot, A., and C. Lacroix. 2003. Effects of micronization on viability and thermotolerance of probiotic freeze-dried cultures. Int. Dairy J. 13:455-462. https://doi.org/10.1016/S0958-6946(03)00050-5.

Ragavan, M. L., and N. Das. 2018. Process optimization for microencapsulation of probiotic yeasts. Front. Biol. (Beijing) 13:197-207. https://doi.org/10.1007/s11515-018-1495-1.

Ré, M. I. 1998. Microencapsulation by spray drying. Dry. Technol. 16:1195-1236. https://doi.org/10.1080/07373939808917460.

Rocha, G. A., M. A. Trindade, F. M. Netto, and C. S. Fávaro-Trindade. 2009. Microcapsules of a casein hydrolysate: Production, characterization, and application in protein bars. Food Sci. Technol. Int. 15:407-413. https://doi.org/10.1177/1082013209346042.

Rosenberg, M., I. J. Kopelman, and Y. Talmon. 1985. A scanning electron microscopy study of microencapsulation. J. Food Sci. 50:139-144. https://doi.org/10.1111/j.1365-2621.1985.tb13295.x.

Salavati Schmitz, S., and K. Allenspach. 2017. Effects of different oligosaccharides on growth of selected probiotic bacterial strains. J. Microb. Biochem. Technol. 9:572-576.

Sharma, A., A. H. Jana, and R. S. Chavan. 2012. Functionality of milk powders and milk-based powders for end use applications-A review. Compr. Rev. Food Sci. Food Saf. 11:518-528. https://doi .org/10.1111/j.1541-4337.2012.00199.x.

Sidlagatta, V., S. V. V. Chilukuri, B. R. Devana, S. D. Dasi, and L. Rangaswamy. 2020. Effect of maltodextrin concentration and inlet air temperature on properties of spray dried powder from reverse osmosis concentrated sweet orange juice. Braz. Arch. Biol. Technol. 63:e20190538.

Silva, J. V., and J. A. O'Mahony. 2017. Flowability and wetting behaviour of milk protein ingredients as influenced by powder composition, particle size and microstructure. Int. J. Dairy Technol. 70:277-286. https://doi.org/10.1111/1471-0307.12368.

Singh, H., D. F. Newstead, and P. F. Fox. 1992. Aspects of proteins in milk powder manufacture. Pages 735-765 in Advanced Dairy Chemistry-1: Proteins. 2nd ed. Elsevier Applied Science.

Sosa, N., E. Gerbino, M. A. Golowczyc, C. Schebor, A. Gómez-Zavaglia, and E. E. Tymczyszyn. 2016. Effect of galacto-oligosaccharides: Maltodextrin matrices on the recovery of Lactobacillus 
plantarum after spray-drying. Front. Microbiol. 7:584. https://doi org/10.3389/fmicb.2016.00584.

Sun, W., and M. W. Griffiths. 2000. Survival of Bifidobacteria in yogurt and simulated gastric juice following immobilization in gellan-xanthan beads. Int. J. Food Microbiol. 61:17-25. https://doi .org/10.1016/S0168-1605(00)00327-5.

Tripathi, M. K., and S. K. Giri. 2014. Probiotic functional foods: Survival of probiotics during processing and storage. J. Funct. Foods 9:225-241. https://doi.org/10.1016/j.jff.2014.04.030.

Westergaard, V. 2004. Analytical methods raw milk, concentrate and powder properties. Pages 203-213 in Milk Powder Technology: Evaporation and Spray Drying. 1st ed. GEA Process Engineering.

Wilkinson, M. G. 2018. Flow cytometry as a potential method of measuring bacterial viability in probiotic products: A review. Trends Food Sci. Technol. 78:1-10. https://doi.org/10.1016/j.tifs.2018.05 .006 .

Xu, M., F. Gagné-Bourque, M. J. Dumont, and S. Jabaji. 2016. Encapsulation of Lactobacillus casei ATCC 393 cells and evaluation of their survival after freeze-drying, storage and under gastrointestinal conditions. J. Food Eng. 168:52-59. https://doi.org/10.1016/ j.jfoodeng.2015.07.021.

Yang, S., X. Y. Mao, F. F. Li, D. Zhang, X. J. Leng, F. Z. Ren, and G. X. Teng. 2012. The improving effect of spray-drying encapsulation process on the bitter taste and stability of whey protein hydroly- sate. Eur. Food Res. Technol. 235:91-97. https://doi.org/10.1007/ s00217-012-1735-6.

Yasmin, I., M. Saeed, I. Pasha, and M. A. Zia. 2019. Development of whey protein concentrate-pectin-alginate based delivery system to improve survival of $B$. longum BL-05 in simulated gastrointestinal conditions. Probiotics Antimicrob. Proteins 11:413-426. https:// doi.org/10.1007/s12602-018-9407-x.

Ying, D., J. Sun, L. Sanguansri, R. Weerakkody, and M. A. Augustin. 2012. Enhanced survival of spray-dried microencapsulated Lactobacillus rhamnosus GG in the presence of glucose. J. Food Eng. 109:597-602. https://doi.org/10.1016/j.jfoodeng.2011.10.017.

Zanjani, M. A. K., B. G. Tarzi, A. Sharifan, and N. Mohammadi. 2014 Microencapsulation of probiotics by calcium alginate-gelatinized starch with chitosan coating and evaluation of survival in simulated human gastro-intestinal condition. Iran J. Pharm. Res. 13:843.

Zhang. W., and Q. Zhong. 2010. Microemulsions as nanoreactors to produce whey protein nanoparticles with enhanced heat stability by thermal pretreatment. Food Chem. 119:1318-1325. https://doi .org/10.1016/j.foodchem.2009.08.043.

\section{ORCIDS}

Sanjeev Anand ๑ https://orcid.org/0000-0002-7479-9965 